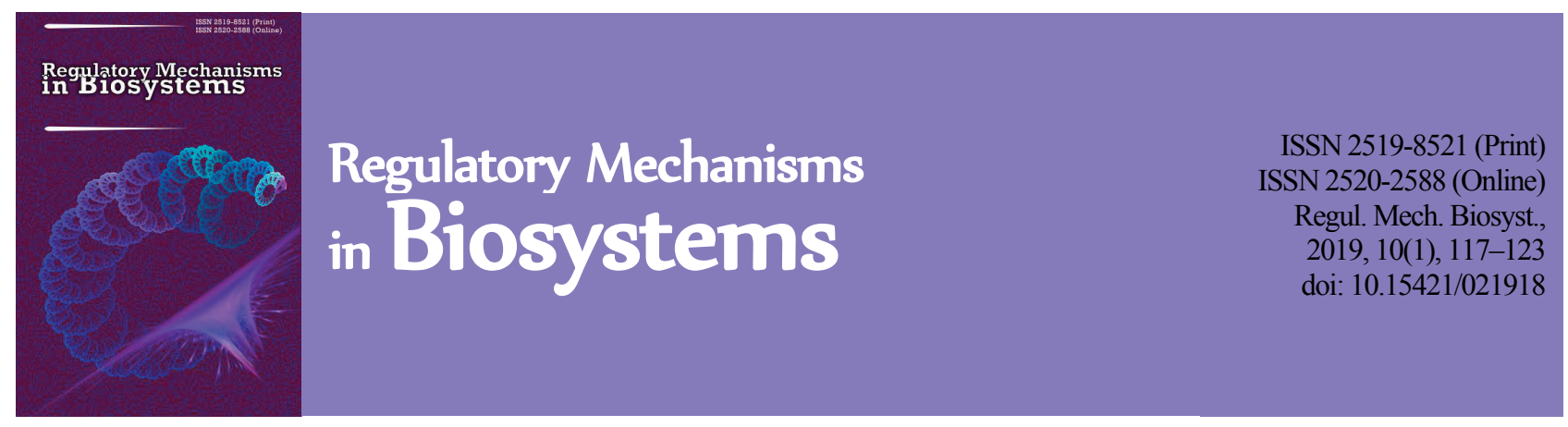

\title{
Legionella, water and biotechnology
}

\author{
A. D. J. Cortés-Sánchez \\ Consejo Nacional de Ciencia y Tecnología (CONACYT), Unidad Nayarit del Centro de Investigaciones Biológicas del Noroeste \\ (UNCIBNOR+), Nayarit, México
}

Article info

Received 24.03.2019

Received in revised form 20.04.2019

Accepted 23.04.2019

Consejo Nacional de Ciencia y Tecnología (CONACYT), Unidad Nayarit del Centro de

Investigaciones Biológicas del

Noroeste (UNCIBNOR+), Calle

Dos No. 23, Cd. del Conocimiento,

Av. Emilio M. González,

Cd. Industrial, C.P. 63173

Tepic, Nayarit. México.

E-mail:alecortes_1@hotmail.com

Cortés-Sánchez, A. D. J. (2019). Legionella, water and biotechnology. Regulatory Mechanisms in Biosystems, 10(1), 117123. doi:10.15421/021918

Legionella spp. are microorganisms that are generally found in the aquatic environment (rivers, streams, lakes, among others). The importance in public health is in the fact that this bacterium is capable of multiplying and propagating in artificial aquatic systems (piping systems, storage tanks, fountains, and cooling towers), giving rise to diseases in humans called legionellosis, transmitted by inhalation of contaminated water droplets or aerosols and whose complications can lead to the death of the patient. Legionellosis is of worldwide distribution, Legionella pneumophila being the most commonly involved species in outbreaks and reported cases. The people most at risk are the elderly, people with weakened immune systems, and people with a history of smoking. Around the world, regulatory agencies and health organizations have issued and established recommendations with the purpose of controlling and preventing the risk of contracting this disease, which include the sanitation of water supplies, maintenance through regular cleaning and disinfection of facilities and devices for reducing the presence of this pathogen. The main objective of this review is to present in a general manner, aspects related to the disease known as legionellosis, its casual agents, habitat, transmission form, and phenotypic and metabolic characteristics. Likewise, the methods of control and prevention of these pathogens are presented, including a potential biotechnological alternative that can contribute to actions in favour of the protection of public health through the use of compounds with surface activity called biosurfactants.

Keywords: aquatic environment; antimicrobial activity; biosurfactants; public health; waterborne pathogens.

\section{Introduction}

The species of the genus Legionella are natural inhabitants of aquatic environments such as: surface waters of lakes, rivers, reservoirs, ponds, among others, and frequently pollute water systems made by humans (Forjan et al., 2016; Herwaldt \& Marra, 2018; Slow et al., 2018), thus colonizing water supply systems and, through the distribution network, contaminating drinking water storage systems or other systems that require water for different operation (cooling towers, evaporative condensers, swimming pools or ornamental fountains), and provoking diseases of humans (Edelstein \& Luck, 2015; Forjan et al., 2016; Lösch et al., 2016; Clémence et al., 2018; Gea, 2018).

The main objective of this review is to present, in a general manner, aspects related to the disease known as legionellosis, its casual agents, habitat, transmission form, phenotypic and metabolic characteristics. Likewise, the methods of control and prevention of spreading of these pathogens are presented, including a potential biotechnological alternative that can contribute to actions in favour of the protection of public health through the use of compounds with surface activity called biosurfactants.

The representatives of the Legionella genus are Gram-negative rodshaped, mesophilic, mobile, aerobic, weak or non-saccharolytic bacteria, resistant to a wide range of physicochemical conditions, and which depend on L-cysteine for their growth (Gea, 2015; Edelstein \& Luck, 2015; Forjan et al., 2016; Lösch et al., 2016).

Legionella spp. are intracellular bacterial pathogens of humans, mainly in monocytes and alveolar macrophages (Diaz et al., 2011; Edelstein \& Luck, 2015; Forjan et al., 2016; Lösch et al., 2016; Slow et al., 2018; WHO, 2018). Infections caused by these microorganisms are generically called legionellosis, encompassing both pneumonic and nonpneumonic forms of infection by these microorganisms. The non-pneu- monic form manifests clinically as a self-limiting and flu-like illness called "Pontiac Fever". The more severe pneumonia form is known as "Legionnaires' Disease" (Edelstein \& Luck, 2015; Forjan et al., 2016; Lösch et al., 2016; Slow et al., 2018; WHO, 2018). Among the 60 species of the Legionella genus, almost a half have been implicated in human disease. The most important from the clinical perspective are: $L$. longbeachae, L. micdadei, L. dumoffii, L. sainthelensi and L. pneumophila, the latter consists of 14 serogroups and is associated with $90 \%$ of cases of Legionnaires' Disease, especially strains of serogroups 1, 4 and 6; affecting mainly people with deficiency of the immune system, elderly and smokers (Edelstein \& Luck, 2015; Gea, 2015; Forjan et al., 2016; Lösch et al., 2016; Slow et al., 2018).

Dissemination in the air and inhalation of aerosols or water droplets is the most frequent route of infection (García \& Martínez, 2014; Lösch et al., 2016), which also means it is not typically transmitted directly from person to person (Gea, 2015). However, contrary to what has been postulated over the years, the transmission of legionella from person to person has been reported (Borges et al., 2016; Correia et al., 2016). The case fatality rate in the most severe form of infection is between $5-10 \%$, which can reach $80 \%$ in immunosuppressed patients without treatment. The incubation period ranges from 2 to 10 days and up to 16 days. The most frequent symptoms are fever, cough, muscle pain, headache, lethargy, malaise, hemoptysis, diarrhea and nausea (Forjan et al., 2016; CDC, 2018; WHO, 2018).

The probability of developing the disease is a function of the concentration of the microorganism in the water source, production and dispersion of aerosols, factors related to the host, such as age or preexisting conditions, and the virulence of the strain (WHO, 2018). Treatment of Legionella infection involves drugs such as quinolones and macrolides, and prolonged treatment regimens are recommended for people 
with depressed immune systems (Alexandropoulou et al., 2013; García \& Martínez, 2014). However, the isolation of antibiotic-resistant strains of Legionella from aquatic environmental systems and of clinical origin has been reported, which could lead to a possible risk of ineffective treatment in patients with legionellosis, which indicates the need for a surveillance system for this resistance phenomenon in strains from different sources to monitor changes in resistance patterns and generate appropriate clinical treatments (Alexandropoulou et al., 2013; Bruin et al., 2014).

L. pneumophila, in the environment, is an intracellular facultative parasite of different free-living protozoa such as: Acanthamoeba, Hatmannella, Tetrahymena and Naegleria. It also generates biofilms that are formed in water distribution networks; in both cases, those are considered survival mechanisms (Edelstein \& Luck, 2015; Forjan et al., 2016; Clémence et al., 2018; Cortés et al., 2018; Gea, 2018; WHO, 2018).

Legionellosis can be acquired in the community or hospitals, and may occur in the form of outbreaks or in isolated cases (Forjan et al., 2016). It is estimated that Legionnaire's Disease is of worldwide distribution, where the incidence varies considerably depending on the level of surveillance and notification of cases. Given that many countries lack adequate means of diagnosis to detect infection, or do not have robust surveillance systems, the actual incidence rate is unknown (WHO, 2018).

In the United States of America, it is estimated that around 8,000 to 18,000 people each year are hospitalized for Legionnaires' Disease (Herwaldt \& Marra, 2018). In Europe, Legionnaire's Disease is notifiable in the member states of the European Union, where in the period 2011 to 2015 the European Center for Disease Prevention and Control (ECDC), and the European Legionnaires' Disease Surveillance Network (ELDSNet) reported 30,532 cases, of which 28,188 (92.3\%) were confirmed cases and 2,344 (7.7\%) were probable cases; France, Germany, Italy, Spain and the Netherlands reported the greatest number of cases and the main causative agent $L$. pneumophila (Beaute, 2017).

In Latin America the incidence of legionellosis is unknown. In Argentina there are few existing works, possibly due to the presentation in the form of sporadic cases and not outbreaks; an incidence of approximately $2 \%$ of all pneumonias has been reported (Lösch \& Merino, 2016). In Mexico, legionellosis is not a reportable disease (Hampton et al., 2016, Cortés et al., 2018). Until 2011, in Mexico, only two cases with a clinical diagnosis of $L$. pneumophila had been reported, without confirmation by laboratory tests and without isolation of the causative agent; these were from the Mexico states, Guerrero and Quintana Roo (Diaz et al., 2011). The last reported case of legionellosis in Mexico, with laboratory confirmation, involved nine travelers who contracted the disease within two-weeks of staying at the resort of Cozumel, Mexico, between May 2008 and April 2010; it was determined, through different investigations, that the source of common infection was the drinking water system of the hotel complex and the main causal agent identified in the water sample was L. pneumophila serogroup 1 (Hampton et al., 2016; Cortés et al., 2018). Manzanares et al. (2014) carried out a study to determine, for the first time, the presence of $L$. pneumophila in the water systems of the Dental School of the Autonomous University of the State of Mexico, reporting that these systems were infected with Legionella, with counts ranging from 19 to $1000 \mathrm{CFU} / \mathrm{mL}$, being a risk factor for the health of users; it also indicated that the use of water filters minimizes the concentration of this microorganism and that the process of chlorination of drinking water is not an adequate method for sanitary control, as analysis of this type of sample presented the highest concentrations. The studies carried out associated with the control and surveillance of health risks in water, equipment and related systems as sources of risk of legionellosis, seem to be insufficient. This may possibly correspond to the absence or low level of surveillance, detection and prevention of this microorganism in microbiological laboratories or be due to the low incidence of cases (Haro et al., 2012; Cortés et al., 2018). However, it is necessary to make a modification or update in the information system for the regular surveillance and analysis of the microbiological quality of water, water systems and equipment in its different technical regulations, focused on human use and consumption, among which are Official Mexican Standards (NOM) as "NOM-127-SSA1-1994", "NOM-179SSA1-1998”, "NOM-230-SSA1-2002", 'NOM-245-SSA1-2010”,
'NOM-201-SSA1-2015", and "NOM-210-SSA1-2014" of mandatory compliance, elaborated with the purpose of establishing the characterristics that processes, services or products must have that may constitute a risk to human health (Haro et al., 2012; Cortés et al., 2018; SE, 2018). It is also required to place an emphasis on actions that concern the regulation and sanitary inspection of ventilation systems and/or air conditioning in the community and hospital context, generating relevant updates focused on exercising preventive actions and not on post-reaction to future outbreaks of legionellosis that affect public health in Mexico (Haro et al., 2012; Cortés et al., 2018).

\section{Analysis for the detection, control and prevention of legionellosis}

The activities of a microbiology laboratory commonly apply various techniques including phenotypic, molecular and proteomic that allow the isolation, identification and/or detection of microorganisms associated with infectious processes detrimental to health (Bou et al., 2011). In the case of species of Legionella, different methods have been reported for the detection and identification in samples from aquatic systems, based on culture by conventional methodologies and phenotypic characteristics of these bacteria (morphology, development, biochemical and metabolic properties), which also allow further studies of antimicrobial sensitivity, typing and epidemiology (Ausina et al., 2005; Pelaz, 2006; Bou et al., 2011; Borges et al., 2012; Lösch \& Merino, 2016; Cortés et al., 2018). L. pneumophila, the main causative agent of legionellosis, presents different phenotypic characteristics for its identification in culture, as it is a rod-shaped microorganism of $1.5-5.0 \mu \mathrm{m}$ long by 0.5-0.7 $\mu \mathrm{m}$ wide, mobile, catalase positive, uses amino acids as the main source of energy, presents positive gelatin liquefaction, and requires iron salts and L-cysteine for growth.

It also has an optimum growth temperature between $35-37^{\circ} \mathrm{C}$, but it can grow at between 20 and $45^{\circ} \mathrm{C}$, it survives between 40 and $60^{\circ} \mathrm{C}$, dying at $70{ }^{\circ} \mathrm{C}$, it also is resistant to small concentrations of carbon dioxide (Romero, 2007; Ulloa, 2008; Gea, 2015; Cortés et al., 2018). To strengthen the reliability of the results of the microbiological analysis of samples in the laboratory, adequate procedures for collecting samples according to the agent sought are required. For this, the Centers for Disease Control and Prevention of the United States of America (CDC) developed procedures of the isolation and detection of Legionella samples from environmental origin focused on the regular study and/or investigation of outbreaks or associated cases (Ausina, 2005; U.S.D.H.H.S., 2005; CDC, 2015). Among the standardized methods for the detection of Legionella spp. in water samples are those reported by the International Organization for Standardization (ISO) 11731: 1998 (Detection and enumeration of Legionella), ISO 11731-2: 2004 (Detection and enumeration of Legionella, Direct membrane filtration method for waters with low bacterial counts), and the method of the Association Française de Normalisation (AFNOR) NF T 90-431/2003 (Pelaz, 2006; Borges et al., 2012; Rodriguez et al., 2015; Lösch \& Merino, 2016; Cortés et al., 2018). The different methods of microbiological analysis of water share some similarities, being generally constituted in five phases: a. Concentration of the sample, since in the water samples the concentration of Legionella can be low, and in order to recover the bacteria, a membrane filtration or centrifugation can be performed if they are treated with dirty or turbid samples; b. Decontamination and reduction of associated microbiota in the concentrated sample, which is carried out by thermal and acid treatment; c. Inoculation in selective culture media; d. Incubation, and e. Counting, confirmation and typing of isolated colonies (Fig. 1) (Pelaz, 2006; Borges et al., 2012; Rodriguez et al., 2015; Lösch \& Merino, 2016; Cortés et al., 2018). In addition to the conventional method of analysis, there are other alternatives, that can reduce the analysis time, obtain results and perform actions corresponding to control, prevention or treatment, such as the enzyme-linked immunoassay in water with analogous characteristics in the detection of cell wall lipopolysaccharide antigen of L. pneumophila serogroup 1 in urine, and the molecular assays like the Polymerase Chain Reaction (PCR), conventional or real time and both qualitative and quantitative, based on studies of 5S rRNA genes, 16S rRNA and 23S rRNA, mip (macrophage infectivity potentiator) that encodes the infectivity enhancer gene of Legionella in mac- 
rophages, or the dotA infectivity gene (defective organelle trafficking) among others (Ausina et al., 2005; Pelaz, 2006; Borges et al., 2012; Lu et al., 2016; Cortés et al., 2018). In addition, molecular methods such as Whole Genome Sequencing (WGS), Amplified Fragment Length Polymorphism (AFLP), Pulsed-field Gel Electrophoresis (PFGE), and Multilocus Sequence Typing (MLST) are used in the typing and characterrization of strains associated with outbreaks (Ausina, 2005; Rojas \& Figueras, 2006; Borges et al., 2016; Khodr et al., 2016; Raphael et al., 2016; Cortés et al., 2018; Herwaldt \& Marra, 2018).
On the other hand, the identification of Legionella spp., isolations in clinical and environmental samples through proteomic methods using Matrix-Assisted Laser Desorption / Ionization-Time of Flight / Mass Spectrometry (MALDI-TOF) has been reported to be quick and economic (Gaia et al., 2011). In a similar way, an automated in situ independent culture method has been developed for the quantification of Legionella in water, harmonizing stages consisting of preconcentration, immunocapture and magnetic separation of cells with colorimetric techniques (Ripolles et al., 2015; Cortés et al., 2018).
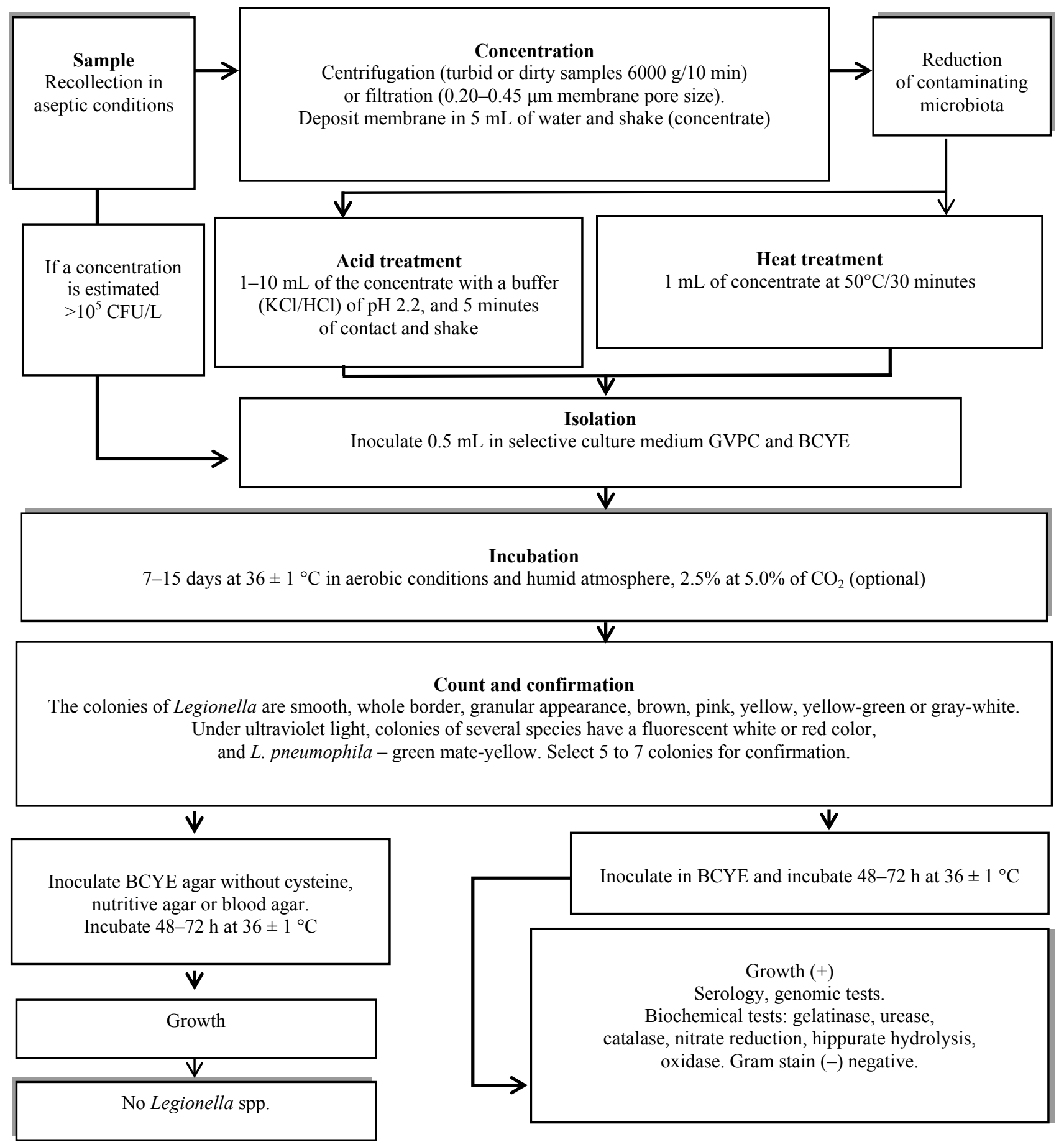

Fig. 1. Flow chart for the detection of Legionella spp., in water samples (ISO 11731: 1998; Ausina, 2005; Pelaz, 2006; Borges et al., 2012; Rodriguez et al., 2015; Lösch \& Merino, 2016) GVPC: BCYE Agar supplemented with glycine, vancomycin, polymyxin B and cycloheximide. BCYE: Buffered Charcoal Yeast Extract Agar

Yamaguchi et al. (2017) developed a rapid (1.5 h) on-site monitoring of $L$. pneumophila in cooling tower water by means of a portable microfluidic system for fluorescent staining on a chip and, for the semiautomatic count of the microorganism in the water of the cooling tower, using a polyclonal antibody labeled with fluorescence. They mention that the limit of detection of the system was $10^{4}$ cells $/ \mathrm{mL}$, also detecting lower numbers of cells ranging from $10^{1}$ to $10^{3}$ cells $/ \mathrm{mL}$ after a concentration process by filtration of 0.5 to $3.0 \mathrm{~L}$ of the water sample. The con- 
clusion of the study was that this system can be effective in the initial analysis of freshwater contamination by Legionella. It should be noted that all these techniques (enzymatic, genomic and proteomic) should not replace culture or standardized tests and should be complementary only (Pelaz, 2006; Borges et al., 2012; Cortés et al., 2018).

\section{Prevention and control of legionellosis}

For the prevention and control of legionellosis, and its potential danger to human health, the knowledge of its ecological niche is of relevance, since Legionella bacteria are microorganisms that inhabit natural aquatic environments, including those of anthropogenic origin, with the capacity to survive a wide range of environmental conditions. Multiple facilities and equipment such as cooling towers, hot water tanks, hydraulic systems, decorative fountains, drinking water systems, hot springs in rehabilitation and recreation centers, whirlpools, decorative fountains, ice making machines, units of transplants and dental units are a sources of exposure and risk of infection, associated with the spreading of legionellosis (Ausina, 2005; Rojas \& Figueras, 2006; Manzanares et al., 2014; Sandrea, 2016; Lösch \& Merino, 2016; Lu et al., 2016; CDC, 2018; WHO, 2018).

Nowadays, there are no vaccines that prevent legionellosis (CDC, 2018; WHO, 2018). The prevention measures are the control and regular monitoring of water quality; the application of mandatory performance measures relating to the hygienic-sanitary condition of facilities, which are aimed at minimizing or avoiding conditions of proliferation and survival of these bacteria, such as the formation of biofilms, and finally reducing or avoiding the diffusion of aerosols through actions involved in the maintenance, cleaning, disinfection and proper functioning of water facilities and related devices (Ausina, 2005; Gea, 2011, 2018; Gea \& Loza, 2012; CDC, 2018; Cortés et al., 2018; WHO, 2018).

\section{Biotechnology in the control and prevention of legionellosis}

For several years up to now, there have been reports about production by different microorganisms (bacteria, fungi and yeast) of a large group of compounds with the ability to reduce the surface and interfacial tension at the air/water and oil/water interfaces, which have been denominated as biosurfactants (BS) (Banat et al., 2010; Nuvia et al., 2014; Cortés et al., 2015; Becerra \& Horna, 2016).

BS are amphiphilic compounds because in their structure they present a hydrophilic region formed by aminoacids, peptides (anions or cations), mono- or polysaccharides, and a hydrophobic region, consisting of saturated and unsaturated fatty acids, which can be secreted extracellularly or be bound to the cell membrane during microbial growth predominantly in water-insoluble substrates (Rodrigues \& Teixeira, 2010; Banat et al., 2014; Nuvia et al., 2014; Becerra \& Horna, 2016; Cortés \& Barrón, 2017).

The BS have acquired relevance due to different properties attributed to them which confer advantages to them compared to surfactants of chemical origin; notably their lower toxicity, their biodegradability, stability at different $\mathrm{pH}$ conditions, salinity and temperature, high selectivity and specificity, their being produced from organic residues, and also their biological activities such as anti-adhesive, antibacterial, anti-fungal, insecticidal, antiviral, immunomodulatory and antitumour properties, so they have been considered as potential alternatives for use in various industrial areas such as food, pharmaceutical, mining, oil, environmental, among others (Gautam \& Tyagi, 2006; Banat et al., 2010; Rodrigues \& Teixeira, 2010; Soberon \& Maier, 2011; Nuvia et al., 2014; Banat et al., 2014; Cortés et al., 2015; Becerra \& Horna, 2016; Cortés \& Barrón, 2017; Sharma et al., 2018).

These biological compounds have a great structural diversity presenting various classifications, as for example according to their molecular weight in two classes:

1. Low molecular weight, such as lipopeptides, glycolipids and proteins.

2. High molecular weight or polymers like saccharides, lipopolysaccharides, proteins or lipoproteins useful for stabilizing oil-in-water emulsions (Banat, 2010).

Or they can also be classified based on their chemical composition, in particular their hydrophilic fraction in glycolipids, lipopeptides or lipoproteins, fatty acids, phospholipids and neutral lipids, polyparticles, and surfactant particles (Table 1) (Gautam \& Tyagi, 2006; Gharaei, 2010; Cortés et al., 2015).

\section{Table 1}

Biosurfactants, use and production by microorganisms (Desai \& Banat, 1997; Singh \& Cameotra, 2004; Hewald et al., 2005; Gautam \& Tyagi, 2006; Rodrigues et al., 2006; Das et al., 2008; Morita et al., 2009; Gharaei, 2010; Saharan et al., 2011; Reis et al., 2011; Banat \& Thavasi, 2018)

\begin{tabular}{|c|c|c|c|}
\hline Biosurfactant & Examples & $\begin{array}{l}\text { Microorganisms } \\
\text { producers }\end{array}$ & $\begin{array}{c}\text { Potential } \\
\text { uses }\end{array}$ \\
\hline Glycolipids & $\begin{array}{l}\text { L-rhamnose linked to } \\
\text { hydroxylated } \beta \text {-fatty } \\
\text { acids RL1(RhC10C10), } \\
\text { RL2 (RhC10), RL3 } \\
\text { (Rh2C10C10) y RL4 } \\
\text { (Rh2C10) }\end{array}$ & $\begin{array}{l}\text { Pseudomonas sp., } \\
\text { P. aeruginosa, } \\
\text { Serratia rubidea }\end{array}$ & $\begin{array}{c}\text { Bioremediation, } \\
\text { antimicrobial, } \\
\text { biocontrol }\end{array}$ \\
\hline Rhamnolipids & $\begin{array}{c}\text { Sophorose (dimeric } \\
\text { sugar) linked by } \beta \text {-glyco- } \\
\text { sidic bonds to hydroxy- } \\
\text { lated fatty acids }\end{array}$ & $\begin{array}{l}\text { Torulopsis bombi- } \\
\text { cola, T. apicola, } \\
\text { T.petrophilum }\end{array}$ & Antimicrobial \\
\hline Sophorolipids & $\begin{array}{l}\text { Disaccharide of trehalose } \\
\text { linked to } \alpha \text {-branched- } \beta \text { - } \\
\text { hydroxylated fatty acids. } \\
\text { Mycolic acids }\end{array}$ & $\begin{array}{l}\text { Mycobacterium spp., } \\
\text { Rodhococcus } \\
\text { erythropolis, Nocar- } \\
\text { dia spp., Corynebac- } \\
\text { terium spp. }\end{array}$ & $\begin{array}{l}\text { Dissolution of } \\
\text { - hydrocarbons, } \\
\text { antiviral }\end{array}$ \\
\hline Trehalolipids & $\begin{array}{l}\text { O-glycosidically bound } \\
\text { cellobiose to } 15,16- \\
\text { hydroxy hexadecanoic } \\
\text { acid, Ustilagic acid }\end{array}$ & $\begin{array}{l}\text { Ustilago maydis, } U \text {. } \\
\text { zeae, Psendozyma } \\
\text { fusiformata }\end{array}$ & Antimicrobial \\
\hline $\begin{array}{l}\text { Cellobiose lipids } \\
\text { Mannosylerythritol }\end{array}$ & $\begin{array}{l}\text { Constituted of 4-O- } \beta \text {-D- } \\
\text { mannopyranose-eryth- } \\
1 \text { ritol and fatty acids in its }\end{array}$ & $\begin{array}{l}\text { Candida antartica, } \\
\text { Pseudozyma sia- } \\
\text { mensis, Ustilago }\end{array}$ & $\begin{array}{l}\text { Antimicrobial, } \\
\text { immunological }\end{array}$ \\
\hline & $\begin{array}{l}\text { hydrophobic fraction. } \\
\text { MEL-A, MEL-B, MEL-C }\end{array}$ & $\begin{array}{l}\text { maydis, } \\
\text { U. scitaminea }\end{array}$ & nronortioc \\
\hline $\begin{array}{l}\text { Fatty Acids, } \\
\text { Phospholipids and } \\
\text { Neutral lipids }\end{array}$ & $\begin{array}{l}\text { Phosphatidyl- } \\
\text { ethanolamine }\end{array}$ & $\begin{array}{l}\text { Acinetobacter spp., } \\
\text { Pseudomonas aeru- } \\
\text { ginosa, Thiobacillus } \\
\quad \text { thiooxidans }\end{array}$ & $\begin{array}{l}\text { Biol } \\
\text { bio }\end{array}$ \\
\hline $\begin{array}{l}\text { Lipoproteins and } \\
\text { lipopeptids }\end{array}$ & $\begin{array}{l}\text { Gramicidin, polymyxin, } \\
\text { surfactin, subtilisin, } \\
\text { serrawettins, viscosin, } \\
\text { iturin and lichenysin }\end{array}$ & $\begin{array}{l}\text { Bacillus subtillis, } \\
\text { B. licheniformis, } B \text {. } \\
\text { brevis, B. polymyxa, } \\
\text { Serratia marcescens }\end{array}$ & $\begin{array}{l}\text { Emulsifiers, } \\
\text { anti adhesive, } \\
\text { antimicrobial }\end{array}$ \\
\hline $\begin{array}{l}\text { Surfactant } \\
\text { particles }\end{array}$ & $\begin{array}{l}\text { Membrane vesicles com- } \\
\text { posed of phospholipid } \\
\text { and proteins, lipopoly- } \\
\text { saccharides }\end{array}$ & $\begin{array}{l}\text { Acinetobacter } \\
\text { calcoaceticus, } \\
\text { Pseudomonas } \\
\text { marginilis }\end{array}$ & Bioremediation \\
\hline $\begin{array}{l}\text { Polymeric } \\
\text { surfactants }\end{array}$ & $\begin{array}{c}\text { Emulsan, liposan, alazan, } \\
\text { manoproteins and } \\
\text { protein-polysaccharide } \\
\text { complexes }\end{array}$ & $\begin{array}{l}\text { Acinetobacter } \\
\text { calcoaceticus, } \\
\text { A. radioresistens, } \\
\text { Candida lipolytica, } \\
\text { C. tropicalis, } \\
\text { Saccharomyces } \\
\text { cerevisiae }\end{array}$ & $\begin{array}{c}\text { Bioremediation, } \\
\text { oil recovery }\end{array}$ \\
\hline
\end{tabular}

The biosynthesis of these compounds with surface activity in its qualitative and quantitative aspects is affected by different factors, which include those of environmental character (temperature, aeration, speed of agitation, $\mathrm{pH}$ and salinity), as well as those inherent in nature of the carbon and nitrogen source used (Rahman \& Gakpe, 2008; Saharan et al., 2011; Cortés et al., 2015). The biosurfactants in the producer cells, since they are components of metabolism, have several functions, which are involved in growth and survival such as: increase in the surface area and bioavailability of hydrophobic substrates, metal sequestering agents, activity in the microbial pathogenesis, antimicrobial activity, quorum sensing, joining and separation of surfaces, as well as the formation of biofilms (Ron \& Rosenberg, 2001; Rodrigues \& Teixeira, 2010; Banat et al., 2014).

A biofilm is defined as a group or communities of microorganisms of either the same or different species that adhere to and colonize a solid surface or substrate (plastic, metal, glass, soil particles, wood, medical material for implants, tissues, food, among others) and which includes extracellular material produced and trapped within a general matrix of complex nature (Nitschke \& Costa, 2007; Kiran et al., 2010; Tilahun et al., 
2016; Ripolles \& Rodriguez, 2018). Legionella spp., are microorganisms able to form biofilms. The formation of biofilms is considered a protection mechanism for various microorganisms against adverse environmental conditions and antimicrobials (Kiran et al., 2010; Gea, 2011; Banat et al., 2014; Tilahun et al., 2016; Ripolles \& Rodriguez, 2018; Sharma et al., 2018). It is known that Legionella concentrations are generally higher in areas where biofilms are present, as well as protozoa that act as hosts that are located within the biofilms of aquatic origin. As a consequence of the presence of biofilms, there could be a high risk of transmission of legionellosis, from environmental and artificial aquatic sources, primarily cooling towers, analogous equipment and water distribution systems where they can survive and proliferate (Gea \& Loza, 2012). Moreover from the perspective of the industrial sphere, and in particular those of food and public health, biofilms are a relevant issue because their existence represents a potential problem as they can act as a transmission vehicle and source of persistent microbiological contamination, leading to serious hygiene problems, deterioration of food and manufacturing equipment, as well as hindering and harming processes by generating the reduction of pipe flow, heat transfer, membrane obstruction, energy loss, increased corrosion of surfaces, among others, and leading also to considerable economic losses (Navia et al., 2010; Tilahun et al., 2016; Ripolles \& Rodriguez, 2018; Sharma et al., 2018).

There are different studies that report the isolation of multiple microorganisms from different natural environments producing biosurfactants; these chemical compounds can also be considered as potential candidates in the control and prevention of the formation of biofilms of different microorganisms including Legionella spp., due to their surface activity, anti-adhesive and antimicrobial properties (Banat et al., 2010; Kira et al., 2010; Marchant \& Banat, 2012; Banat et al., 2014; Clémence et al., 2015).

Different studies on the interaction of BS with microorganisms harmful to health indicate the benefits of using biosurfactants with the ability to prevent or interrupt biofilms by reducing adhesion, which in combination with biocidal agents could represent an alternative antimicrobial strategy in different areas such as the food industry, the environment (because they are less toxic and biodegradable than surfactants of synthetic origin) and health, since antimicrobials are generally less effective against biofilms than planktonic cells; thus, the interruption of the biofilm by the biosurfactant can facilitate the access of biocidal agents to the target cells (Nitschke \& Costa, 2007).

Among the biosurfactants, those considered low molecular weight glycolipids type (rhamnolipids and sophorolipids) and lipopeptides consisting of a hydrophilic fraction (peptides) linked to fatty acids, such as surfactins, polymixins, fengycins, fusaricidins, lichenysin and iturin, have shown the capacity to prevent the formation and dispersion of biofilms and are considered candidates for use in the eradication of microorganisms including pathogens (Banat et al., 2014; Coronel et al., 2015; Bernat et al., 2016; Clémence et al., 2018).

The surfactin produced by $B$. subtilis shows an antimicrobial spectrum to the genus Legionella spp., with a minimum inhibitory concentration of 1 to $4 \mu \mathrm{g} / \mathrm{mL}$, also having a weak activity towards the amoeba Acanthamoeba castellanii, which is considered a natural reservoir of L. pneumophila. The anti-biofilm assays showed that $66 \mu \mathrm{g} / \mathrm{mL}$ of the surfactin eliminated $90 \%$ of a 6 -day biofilm. This study, which reveals the activity of the surfactin against Legionella spp. and biofilms, indicates its potential to be used to control the spread of Legionella (Clémence et al., 2015).

Clémence et al. (2018) reported the synthesis of lipopeptide-type biosurfactants and glycolipids (rhamnolipids) of strains of Pseudomonas spp., with antimicrobial activity against Legionella pneumophila, thus indicating the multifunctionality of these biomolecules and biotechnological potential where their use as antimicrobials stands out in biological control in the water treatment industry. However, the author highlights the need for more experimental information to evaluate the efficacy of biosurfactants under real conditions.

BS is a group of compounds of structural diversity and is also considered a promising alternative which can be applied in multiple industrial fields due to the different physicochemical and biological properties presented. However, the production and use of BS on a large scale are still limited due to the high costs of production optimization, as well as the need for greater knowledge about producer microorganisms, metabolic and genomic processes of their synthesis, and interactions of cells and the environment (Rahman \& Gakpe, 2008; Banat et al., 2010; Cortés et al., 2015).

\section{Conclusions}

Legionella spp., are considered opportunistic pathogens which have become important in public health due to their high rates of occurrence and mortality. These bacteria are present in aquatic ecosystems as a natural habitat as well as having the characteristic of surviving diverse physicochemical conditions. Therefore, water becomes a transmitting vehicle when colonizing human manufacturing systems and equipment that make use of this natural resource, thus generating a potential risk to health.

The prevention and control of possible cases or outbreaks of legionellosis may require joint actions in the control and regular monitoring of the microbiological quality of water, as well as the development and implementation of regular programmes for cleaning and disinfecting water and ventilation systems and equipment for human use.

Biosurfactants are compounds with surface activity produced by different microorganisms which have shown multiple properties such as surface activity, low toxicity, biodegradability, stability at different $\mathrm{pH}$ conditions, temperature and salinity, antimicrobial activity, among others; this places them as a potential biotechnological alternative, considering their limitations in cost and production, to act as a coadjutant in control and prevention measures specifically in hygiene and sanitation actions of water systems and equipment, preventing their colonization and formation of biofilms, which are considered the source and amplifiers of various pathogens that put human health at risk including the causal agents of legionellosis.

\section{References}

AFNOR (2003). Water quality. Detection and enumeration of Legionella spp. and Legionella pneumophila. Method by direct inoculation and after concentration by membrane filtration of centrifugation. AFNOR NF T90-431. Association Française de Normalisation, La Plaine Saint-Denis, France.

Alexandropoulou, I. G., Parasidis, T. A., Konstantinidis, T. G., Constantinidis, T. C., \& Panopoulou, M. (2013). Antibiotic susceptibility surveillance of environmental Legionella strains: Application of the E-test to bacteria isolated from hospitals in Greece. Journal of Infectious Diseases and Therapy, 2(1), $1000 \mathrm{e} 103$

Ausina, V., Catalán, V., Cercenado, E., \& Pelaz, A. C. (2005). Recommendations of the Spanish Society of Infectious Diseases and Clinical Microbiology. In: Cercenado, E. \& Cantón, R. (Ed.). Procedures in Clinical Microbiology. SEIMC. Pp. 1-72. Microbiological diagnosis and control of legionellosis.

Banat, I. M., De Rienzo, M. A. D., \& Quinn, G. A. (2014). Microbial biofilms: Biosurfactants as antibiofilm agents. Applied Microbiology and Biotechnology, 98(24), 9915-9929.

Banat, I. M., Franzetti, A., Gandolfi, I., Bestetti, G., Martinotti, M. G., Fracchia, L., \& Marchant, R. (2010). Microbial biosurfactants production, applications and future potential. Applied Microbiology and Biotechnology, 87(2), 427-444.

Banat, I., \& Thavasi, R. (Ed.). (2018). Microbial biosurfactants and their environmental and industrial Applications. CRC Press, Taylor \& Francis Group, Boca Raton.

Beauté, J. (2017). Legionnaires' disease in Europe, 2011 to 2015. Eurosurveillance, 22(27), 30566.

Becerra, G. L. K., \& Horna, A. M. V. (2016). Isolation of biosurfactant producing microorganisms and lipases from wastewaters from slaughterhouses and soils contaminated with hydrocarbons. Scientia Agropecuaria, 7, 23-31.

Bernat, P., Paraszkiewicz, K., Siewiera, P., Moryl, M., Płaza, G., \& Chojniak, J. (2016). Lipid composition in a strain of Bacillus subtilis, a producer of iturin A lipopeptides that are active against uropathogenic bacteria. World Journal of Microbiology and Biotechnology, 32, 157.

Borges, A., Simões, M., Martínez, M. A., \& Saavedra, M. J. (2012). Detection of Legionella spp. in natural and man-made water systems using standard guidelines. Journal of Microbiology Research, 2(4), 95-102.

Borges, V., Nunes, A., Sampaio, D. A., Vieira, L., Machado, J., Simões, M. J., Gonçalves, P., \& Gomes, J. P. (2016). Legionella pneumophila strain associated with the first evidence of person-to-person transmission of Legionnaires' disease: A unique mosaic genetic backbone. Scientific Reports, 6, 26261. 
Bou, G., Fernández, O. A., García, C., Sáez, N. J. A., \& Valdezate, S. (2011). Bacterial identification methods in the microbiology laboratory. Enfermedades Infecciosas y Microbiología Clínica, 29(8), 601-608.

Bruin, J. P., Koshkolda, T., Ijzerman, E. P., Lück, C., Diederen, B. M., Den Boer, J. W., \& Mouton, J. W. (2014). Isolation of ciprofloxacin-resistant Legionella pneumophila in a patient with severe pneumonia. Journal of Antimicrobial Chemotherapy, 69(10), 2869-2871.

CDC (2015). Centers for Disease Control and Prevention. Sampling procedure and potential sampling sites. Protocol for collecting environmental samples for Legionella culture during a cluster or outbreak investigation or when cases of disease may be associated with a facility. U.S. Department of Health \& Human Services.

CDC (2018). Centers for Disease Control and Prevention. Legionella (Legionnaires' disease and pontiac fever). National Center for Immunization and Respiratory Diseases, Division of Bacterial Diseases. U.S. Department of Health \& Human Services.

Clémence, L., Margot, S., Renaud, B., Joanne, B., Jean Marc, B., \& Julien V. (2015). Surfactin from Bacillus subtilis displays an unexpected anti-Legionella activity. Applied Microbiology and Biotechnology, 99(12), 5083-5093.

Clémence, L., Portier, E., Corre, M. H., Schlusselhuber, M., Depayras, S., Berjeaud, J. M., \& Verdon, J. (2018). Highlighting the potency of biosurfactants produced by Pseudomonas strains as anti-Legionella agents. BioMed Research International, 2018, Article ID 8194368

Coronel, L. J., Marqués, A. M., Bastida, J., \& Manresa, A. (2016). Optimizing the production of the biosurfactant lichenysin and its application in biofilm control. Journal of Applied Microbiology, 120(1), 99-111.

Correia, A. M., Ferreira, J. S., Borges, V., Nunes, A., Gomes, B., Capucho, R., \& Guerreiro, M. (2016). Probable person-to-person transmission of Legionnaires' disease. New England Journal of Medicine, 374(5), 497-498.

Cortés, S. A. D. J., \& Barrón, S. L. R. (2017). The genus Enterococcus spp., a perspective from a focus on health to its biotechnological application. Scientific Journal of Biological Sciences, 6(1), 191-205.

Cortés, S. A. D. J., Díaz, R. M., Hernández, A. A. J., García, O. F., Villanueva, C. A. León, L. L., \& San Martin, A. A. L. (2015). Bio surfactants produced by enterobacterial. Global Advanced Research Joumal of Microbiology, 4(9), 103-112.

Cortés, S. A. D. J., Espinosa, C. L. D., \& Díaz, R. M. (2018). Legionella spp., a hazard to human health. Agroproductividad, 11(11), 53-58

Das, P., Mukherjee, S., \& Sen, R. (2008). Genetic regulations of the biosynthesis of microbial surfactants: An overview. Biotechnology and Genetic Engineering Reviews, 25, 165-186.

Desai, J. D., \& Banat, I. M. (1997). Microbial production of surfactants and their commercial potential. Microbiology and Molecular Biology Reviews, 61(1), $47-64$.

Diaz, D. G. C., Carrasco, I. R. Z., Lozano, J. C., \& Cahuich, J. I. Á. (2011). Legionelosis, una enfermedad olvidada en México. Revista de Enfermedades Infecciosas en Pediatría, 24, 39-42.

Edelstein, P. H., \& Lück, C. (2015). Legionella. In: Jorgensen, J., Pfaller, M., Carroll, K., Funke, G., Landry, M., Richter, S., \& Warnock, D. (Ed.). Manual of clinical microbiology. Eleventh edition. ASM Press, Washington. Pp. 887-904.

Forján, L. E., García, O. M. M., Piñero, M. Á., Forján, D. M., \& Carrasco, Z. R. (2016). Considerations on updating the Spanish legislation on legionelosis. Ars Pharmaceutica, 57(1), 11-22.

Gaia, V., Casati, S., \& Tonolla, M. (2011). Rapid identification of Legionella spp. by MALDI-TOF MS based protein mass fingerprinting. Systematic and Applied Microbiology, 34(1), 40-44.

García, D. V. I., \& Martínez, A. E. (2014). Legionella infections. Medicine-Programa de Formación Médica Continuada Acreditado, 11(52), 3063-3067.

Gautam, K. K., \& Tyagi, V. K. (2006). Microbial surfactants: A review. Journal of Oleo Science, 55(4), 155-166.

Gea, I. E. (2011). Legionnaires' disease prevention in water cooling systems. Dyna, 78(165), 9-17.

Gea, I. E. (2015). Legionellosis: A new reality in the Republic of Ecuador? Revista Salud Uninorte, 31(2), 385-393.

Gea, I. E. (2018). Water disinfection methods and their affect on legionelosis. Tecnología y Ciencias del Agua, 9(3), 29-46.

Gea, I. E., \& Loza, M. M. (2012). Water quality and health: Biofilms and Legionella. Journal of the Selva Andina Research Society, 3(2), 45-51.

Gea, I. E., Mezones, H. E., \& Haro, G. L. (2012). Actions for legionellosis prevention and control: A challenge for public health in Spain. Revista Peruana de Medicina Experimental y Salud Pública, 29, 272-276.

Gharaei, F. E. (2010). Biosurfactants in pharmaceutical industry: A mini-review. American Journal of Drug Discovery and Development, 1, 58-69.

Hampton, L. M., Garrison, L., Kattan, J., Brown, E., Kozak, M. N. A., Lucas, C. \& Waterman, S. (2016). Legionnaires' disease outbreak at a resort in Cozumel, Mexico. Open Forum Infectious Diseases, 3(3), ofw170.

Haro, A. J., Nubes, G., \& Calderón, O. J. R. (2012). Riesgos sanitarios en calidad microbiológica del agua. Una evaluación en 10 estados de la república mexicana. Región y Sociedad, 24(3), 257-288.
Herwaldt, L. A., \& Marra, A. R. (2018). Legionella: A reemerging pathogen. Current Opinion in Infectious Diseases, 31(4), 325-333.

ISO International Organization for Standardization (1998). ISO 11731:1998. Water quality - Detection and enumeration of Legionella.

ISO International Organization for Standardization (2004). ISO 11731-2:2004. Water quality - Detection and enumeration of Legionella - Part 2: Direct membrane filtration method for waters with low bacterial counts.

Khodr, A., Kay, E., Gomez, V. L., Ginevra, C., Doublet, P., Buchrieser, C., \& Jarraud, S. (2016). Molecular epidemiology, phylogeny and evolution of Legionella. Infection, genetics and evolution, 43, 108-122.

Kiran, G. S., Sabarathnam, B., \& Selvin, J. (2010). Biofilm disruption potential of a glycolipid biosurfactant from marine Brevibacterium casei. FEMS Immunology and Medical Microbiology, 59(3), 432-438

Loret, J. F., Robert, S., Thomas, V., Levi, Y., Cooper, A. J., \& McCoy, W. F. (2005). Comparison of disinfectants for biofilm, protozoa and Legionella control. Journal of Water and Health, 3, 423-433.

Lösch, L. S., \& Merino, L. A. (2016). Presence of Legionella spp. in household drinking water reservoirs in Resistencia, Chaco, Argentina. Preliminary report. Revista Argentina de Microbiología, 48(4), 329-332.

Lu, J., Struewing, I., Vereen, E., Kirby, A. E., Levy, K., Moe, C., \& Ashbolt, N (2016). Molecular detection of Legionella spp. and their associations with Mycobacterium spp., Pseudomonas aeruginosa and amoeba hosts in a drinking water distribution system. Journal of Applied Microbiology, 120(2), 509-521.

Manzanares, L. G. L., Montiel, B. N. M., Del Real, S. S. G. M. E., \& Flores, C. R. I. (2014). Detection of Legionella pneumophila in the water supply systems at the Autonomous University of the State of Mexico's (UAEM) Faculty of Dentistry. Revista ADM, 71(5), 216-220.

Marchant, R \& Banat, I. M. (2012). Microbial biosurfactants: Challenges and opportunities for future exploitation. Trends in Biotechnology, 30(11), 558-565.

Morita, T., Ishibashi, Y., Fukuoka, T., Imura, T., Sakai, H., Abe, M., \& Kitamoto, D. (2009). Production of glycolipid biosurfactants, mannosylerythritol lipids, by a smut fungus, Ustilago scitaminea NBRC 32730. Bioscience, Biotechnology, and Biochemistry, 73(3), 788-792.

Navia, D. P., Villada, H. S., \& Mosquera, S. A. (2010). Biofilms in the food industry. Biotecnología en el Sector Agropecuario y Agroindustrial, 8(2), $118-128$.

Nitschke, M., \& Costa, S. G. V. A. O. (2007). Biosurfactants in food industry. Trends in Food Science and Technology, 18(5), 252-259.

Nuvia, L., Sánchez, S. E., \& Ortiz, H. M. L. (2014). Biosurfactantes y su papel en la biorremediación de suelos contaminados con plaguicidas. Revista Latinoamericana de Biotecnología Ambiental y Algal, 5(1), 47-67.

Pelaz, A. C. (2006). Methods for Legionella detection. Revista de Salud Ambiental, $6,80-84$

Rahman, K. S. M., \& Gakpe, E. (2008). Production, characterization and applications of biosurfactants - Review. Biotechnology, 7(2), 360-370

Raphael, B. H., Baker, D. J., Nazarian, E., Lapierre, P., Bopp, D., Kozak Muiznieks, N. A., \& Winchell, J. M. (2016). Genomic resolution of outbreak-associated Legionella pneumophila serogroup 1 isolates from New York State. Applied and Environmental Microbiology, 82(12), 3582-3590.

Reis, R. S., Pereira, A. G., Neves, B. C., \& Freire, D. M. (2011). Gene regulation of rhamnolipid production in Pseudomonas aeruginosa - a review. Bioresource Technology, 102(11), 6377-6384

Ripollés, A. A., Solís, I., Ferrer, C., Jiménez, M., \& Roríguez, G. (2015). On-site monitoring and detection system for Legionella in waters. Tecnoaqua, 11, $76-81$.

Ripollés, A. C., \& Rodríguez, J. J. J. (2018). Biofilms: Survival of microorganisms, invisible danger in food. Catalan food safety agency. Generalitat de Catalunya, Agencia de Salut Publica de Catalunya.

Rodrigues, L. R., \& Teixeira, J. A. (2010). Biomedical and therapeutic applications of biosurfactants. In: Sen, R. (Ed.). Biosurfactants. Springer, New York. Pp. 75-87.

Rodrigues, L., Banat, I. M., Teixeira, J., \& Oliveira, R. (2006). Biosurfactants: Potential applications in medicine. Journal of Antimicrobial Chemotherapy, 57(4), 609-618.

Rodriguez, M. S., Blanky, M., Friedler, E., \& Halpern, M. (2015). Legionella spp. isolation and quantification from greywater. MethodsX, 2, 458-462.

Rojas, I. I., \& Figueras, S. M. J. (2006). Microbiological and sampling criteria established in the present Spanish legislation for the control of Legionella. Revista de Salud Ambiental, 6, 89-91.

Romero, C. R. (2007). Microbiología y parasitología humana: Bases etiológicas de las enfermedades infecciosas y parasitarias. Editorial Medica Panamericana, México.

Ron, E. Z., \& Rosenberg, E. (2001). Natural roles of biosurfactants. Environmental Microbiology, 3(4), 229-236.

Saharan, B. S., Sahu, R. K., \& Sharma, D. (2011). A review on biosurfactants: Fermentation, current developments and perspectives. Genetic Engineering and Biotechnology Journal, 1, 1-14. 
SE (2018). Secretaría de Economia. Normas Oficiales Mexicanas. Gobierno de los Estados Unidos Mexicanos. Secretary of Economy. Official Mexican Standards, Government of the United Mexican States.

Sharma, D., Gupta, E., Singh, J., Vyas, P., \& Dhanjal, D. S. (2018). Microbia biosurfactants in food sanitation. In: Galanakis, C. M. (Ed.). Sustainable food systems from agriculture to industry. Academic Press. Pp. 341-368.

Singh, P., \& Cameotra, S. S. (2004). Potential applications of microbial surfactants in biomedical sciences. Trends in Biotechnology, 22(3), 142-146.

Slow, S., Anderson, T., Biggs, P., Kennedy, M., Murdoch, D., \& Cree, S. (2018). Complete genome sequence of Legionella sainthelensi isolated from a patient with legionnaires' disease. Genome Announcements, 6(5), e01588-17.

Soberon-Chavez, G., \& Maier, R. M. (2011). Biosurfactants: A general overview. In: Soberon-Chavez, G. (Ed.). Biosurfactants. Springer, Berlin, Heidelberg. Pp. 1-11.
Tilahun, A., Haddis, S., Teshale, A., \& Hadush, T. (2016). Review on biofilm and microbial adhesion. International Journal of Microbiological Research, 7(3), $63-73$.

Ulloa, M. T. (2008). Legionella pneumophila. Revista Chilena de Infectología, 25(3), 208.

USDHHS (2005). Procedures for the recovery of Legionella from the environment. Public Health Service. Centers for Disease Control and Prevention (CDC). National Center for Infectious Diseases. Division of Bacterial and Mycotic Diseases. Respiratory Disease Laboratory Section. U.S. Department of Health and Human Services.

WHO (2018). Legionellosis. Health topics. World Health Organization.

Yamaguchi, N., Tokunaga, Y., Goto, S., Fujii, Y., Banno, F., \& Edagawa, A. (2017). Rapid on-site monitoring of Legionella pneumophila in cooling tower water using a portable microfluidic system. Scientific Reports, 7(1), 3092. 